\title{
Universiteit
}

Leiden

The Netherlands

\section{Information landscapes and economic practice in the Roman world}

Flohr, M.; Rosillo-López, C.; García Morcillo, M.

\section{Citation}

Flohr, M. (2020). Information landscapes and economic practice in the Roman world. In C. Rosillo-López \& M. García Morcillo (Eds.), Palgrave Studies in Ancient Economies (pp. 205-228). Cham: Palgrave MacMillan. doi:10.1007/978-3-030-54100-2_10

Version: $\quad$ Publisher's Version

License: $\quad$ Licensed under Article 25fa Copyright Act/Law (Amendment Taverne)

Downloaded from: $\quad$ https://hdl.handle.net/1887/3216895

Note: To cite this publication please use the final published version (if applicable). 


\title{
Information Landscapes and Economic Practice in the Roman World
}

\author{
Miko Flohr
}

In assessing the role of asymmetric information in the Roman economy, two questions are fundamental. First, there is the question of the ways in which asymmetric information actually impacted on everyday economic processes, and which institutions or ways of doing things emerged to protect the interests of both parties in a transaction. Second, there is the question of the extent to which the shape or structure of markets in the Roman world and the way in which these developed over time, impacted on the role that asymmetric information actually could play in everyday economic practice. While most other chapters in this volume focus on issues related to the first question, the present chapter explores the second, starting from the idea that it is important to consider the ways in which increasing economic integration in the Roman world, particularly in the Western Mediterranean, changed the playing field for people buying and selling things, and how this affected the role of asymmetric information.

M. Flohr $(\bowtie)$

Universiteit Leiden, Leiden, The Netherlands

e-mail: m.flohr@hum.leidenuniv.nl

(C) The Author(s) 2021

205

C. Rosillo-López, M. García Morcillo (eds.), Managing Information

in the Roman Economy, Palgrave Studies in Ancient Economies, https://doi.org/10.1007/978-3-030-54100-2_10 
Two starting assumptions underlie the argument of this chapter. The first of these is that there is a negative relation between the quality of the circulation of information and the potential role of information asymmetries - real or imagined-in market transactions: if more, and better information is circulating, individual sellers and buyers have to be prepared to be dealing with buyers and sellers that were relatively well-informed; if less information is circulating, or the reliability of information is low, individual sellers and buyers can expect to be dealing with buyers and sellers that are less well-informed, thus opening up the possibility to exploit information asymmetries. ${ }^{1}$ For instance, suppose an itinerant vestiarius selling clothes in several places in the Roman world-a figure well attested in the epigraphic record. ${ }^{2}$ As is clear from Diocletian's Prices' Edict, a wide variation of cloaks and tunics could be on offer on local markets, and these could differ in their material and the quality of weaving, and could be associated with widely varying in prices. ${ }^{3}$ Evaluating the quality of what was on offer required knowledge and, to some extent, a trained eye: buyers would have to evaluate the $\operatorname{cloak}(\mathrm{s})$ on offer on the basis of (a) what the vestiarius in question tells them and (b) what they can see with their own eyes and feel with their hands. Yet there may be quite a bit of visual and even tactile similarity between textiles representing a quite different value. As a consequence, buyers who have a lot of knowledge-for example, because they have recently seen other vestiarii with similar products and thus can compare quality and prices, or who live in an environment where many people are buying such products - will be in a better position to negotiate a fair price than inexperienced buyers who have more limited access to such information. Thus, for a travelling vestiarius, there would be considerably less room to exploit possible asymmetries of information in circumstances where they are likely to encounter well-informed buyers, though at the same time, a thicker market also makes it a bit easier to coordinate prices with colleagues. What is true for tunics and cloaks is in fact true for a broad range of goods, including foodstuffs - when potential buyers have regular access to good information about the level of prices for wheat, oil or wine, there is less room for sellers to exploit any superior

${ }^{1}$ On the role of product and pricing information in the dynamics between buyers and sellers see Akerlof 1970, with Dari-Matiacci et al. 2011.

${ }^{2}$ On vestiarii see, for example, Buonopane 2003; Menella 2000.

${ }^{3}$ See the long lists of prices in Ed. Diocl. 19 (wool, 73 lines) and 26 (linen, >140 lines). 
knowledge of market prices that they may have than in places where potential buyers: had more limited access to good information.

The other assumption underlying this chapter is that information circulates most easily through space via direct encounters between individuals and thus, ceteris paribus, spreads more easily in environments and regions where such direct encounters are more likely to occur, and are more likely to occur between people that do not belong to each other's personal sphere: information may spread easily within households and families, but to have a real impact on the role of information asymmetry in the economy, information, for example, about prices, or about the reliability of certain individual traders, would also need to spread, with relative ease, through the local community, and, ideally, between local communities. Obviously, there may be cultural and strategic factors inhibiting the circulation of economic information between different social groups, but as these will have varied only to a limited extent within the Roman Empire, two basic factors seem to be of key significance for the circulation of information: the sheer proximity of larger quantities of people, and the likelihood that these people encountered each other on a regular basis and had incentives to share information. This points to the importance of understanding the spatial (and temporal) dynamics of information networks, both on the macro-scale-between communities-and on the microscale-within communities.

The crucial role of (information) networks in everyday economic practice has, in very general terms, been broadly acknowledged by most economic historians of the Roman world: ever since Horden and Purcell's The Corrupting Sea, 'connectivity' has been a central concept in discourse on trade and transport over longer distances. ${ }^{4}$ There has been ample debate about the (bad) quality of economic information in many places in the Roman Empire, and about the shortcomings of information circulationthere is ample evidence that even between neighboring cities, crucial information was not always circulating. ${ }^{5}$ Yet, while the shortcomings of information circulation in the Greco-Roman Mediterranean may be evident, there has been very limited debate about the way in which these developed under the specific circumstances brought about by the Roman Empire. Indeed, a lot of the discourse about connectivity, traffic, and transport has remained rather theoretical in nature, and has focused on the

\footnotetext{
${ }^{4}$ Horden and Purcell 2000.

${ }^{5}$ Bang 2008: 137-138.
} 
general problems with movement and transport over longer distances over land, river, and sea, without a lot of sensitivity to the emerging geographical realities of the Roman world. ${ }^{6}$ Thus, there has been a lot of debate about the differences in cost, speed, and reliability between road, river, and maritime traffic, but mostly independent of real places and real traffic routes, even if occasional observations have been made. ${ }^{7}$ This essentially even applies to Scheidel's model of the 'shape' of the Roman world which analyzes these theoretical considerations geographically, using a simplified model of the Roman world, that does not incorporate key demographic realities like the spread of urbanism. ${ }^{8}$ It may be argued that, in debates about trade and markets in the Roman world, there also has been a certain (implicit) tendency to conflate the movement of goods with the movement of information, while in reality, goods and information may move by different means and at different speeds between similar places, with the movement of information being significantly less complicated-particularly, using lots of roads is less of an issue if you are not carrying anything. This means that price information may travel much faster than the products themselves, particularly in the case of bulk goods. Secondly, it can be argued that the focus of discourse on information circulation has remained firmly on the macro-scale-that is, on the movement of information over longer distances - without a lot of consideration for the ways in which information might have travelled on the micro-scale: recent discourse has emphasized inter-city movement, but it has had a lot less to say about the movement of information within cities or between cities and the surrounding countryside. Yet the circulation of information in smaller geographical contexts is not intrinsically straightforward. Particularly for economic actors operating outside their immediate social sphere, a range of practical problems began upon entering a foreign city gate, perhaps the simplest of which was finding out the way to the forum. Even if there were ways around this for traders, for instance by forging carefully maintained ties of trust and friendship in a range of communities, or by grouping together in trading associations, there also were occasions when traders or other economic actors arrived at a place where they had to start

${ }^{6}$ See esp. Bang 2008, but also Morley 2007a, 2007b, and, on the other side of the interpretative spectrum, Temin 2013.

${ }^{7}$ See esp. Adams 2012.

${ }^{8}$ Scheidel 2014. 
more-or-less from scratch and had little knowledge of the local market situation in advance. ${ }^{9}$

It may be argued that what is lacking from the debate is, essentially, a proper network perspective on the spatial circulation of information. This chapter will explore such a network perspective, focusing on the nature of the ties between places and people, and on the nature of the dots connecting these ties. It will discuss the historical geography of information networks in the Roman world, and how the way in which the Roman world developed changed the ways in which these information networks functioned. To some extent, information simply followed the movement of goods, and it will not need elaborate argumentation that trade-routes serving the needs of major consumption centers-the Roman Metropolis, which dominated Mediterranean trade networks, and the legions on the frontiers along the Rhine and the Danube-could easily serve as information highways. ${ }^{10}$ However, there were consumers elsewhere in the empire as well, and these equally constituted markets that could be targeted by vestiarii and other traders. A more challenging question is how information networks worked and developed in these contexts. One way to approach this issue is by looking at how actual social ties were used to bridge larger geographical gaps-Wim Broekaert has, in recent years, done valuable work on this aspect the Roman economy, and so have several others. ${ }^{11}$ This chapter will, however, approach these information networks through their actual geographical shape, assessing the way in which the ties of these networks were connected at the points where they came together-in cities, through physical urban infrastructure. It will argue that over time, changes to both the geographical shape and the nodal infrastructure of information networks in the Roman world were dramatic-through road construction, the foundation or emergence of new urban settlements, and urban construction activity-and that this transformed both the information landscape and the role of asymmetric information in the Roman economy.

\footnotetext{
${ }^{9}$ Cf. Bang 2008: 137 on the problem of pre-industrial merchants not having accurate market information on arrival in a city.

${ }^{10}$ See, for example, Erdkamp 2005: 190: "good information on market conditions was much easier to obtain along the busy shipping lanes than on isolated coasts".

${ }^{11}$ Broekaert 2013, 2015. See also recent discourse on trading communities Bang 2008: 239-89; Rice 2016; Terpstra 2013; Verboven 2011.
} 


\subsection{Urban Networks}

Starting at the macro-scale, it should be observed that, even if the city over time became a key phenomenon in virtually all parts of the Roman world, the actual evidence for urban culture is not equally divided over Rome's imperial geography. ${ }^{12}$ In substantial parts of the Roman Empire cities remained few, and often far in between, even in the imperial period; at the same time, there were several regions where urbanism was booming, with many towns emerging at a sometimes very close distance of each other; several regions fell between these two extremes, with urban centers at regular intervals, but not necessarily within each other's direct environment. Figure 10.1 shows a distribution map of the evidence for urban culture. It has been compiled on the basis of epigraphic and archaeological evidence for key aspects of Roman urban culture, including bathing, euergetism, spectacles, spectacle architecture, and monetary culture. The inscriptions have been collected in the two leading epigraphic databases of the moment, the Epigraphische Datenbank Clauss Slaby and the Packard Humanities Searchable Greek Inscriptions, based on a range of searches. ${ }^{13}$ The archaeological evidence, including theaters, amphitheaters, stadiums, hippodromes and public bath buildings, was compiled on the basis of the catalogues that have been published over the course of the past decades. ${ }^{14}$ While not all inscriptions and buildings have been easily or precisely dated, both the epigraphic and the archaeological evidence have a chronological emphasis on the first two centuries $\mathrm{AD}$, and essentially conform to the picture emerging from earlier scholarship. ${ }^{15}$ The map uses a grayscale to highlight the density in the number of places where evidence is found: darker colors indicate a larger concentration of places-mostly cities,

\footnotetext{
${ }^{12}$ The most recent book-length survey on Roman urban geography is Hanson 2016.

${ }^{13}$ Search terms used, by category: monetary culture: pecunia sua, sua pecunia, denarius,

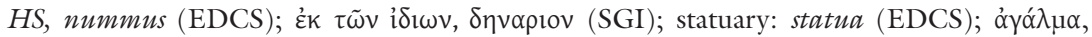
$\alpha v \delta \rho \imath \alpha \varsigma, \varepsilon i k \tilde{\omega} v$ (SGI); spectacle architecture: amphitheatrum, circus, theatrum (EDCS);

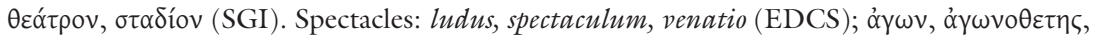

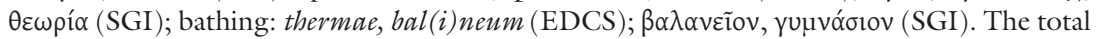
amount of inscriptions underlying the map of Fig. 10.1 is 11.591. A full overview of the database used, and a live version of the map in Fig. 10.1 are available via http://www.mikoflohr.org/romanworld/

${ }^{14}$ For example, Golvin 1988; Humphrey 1986; Manderscheid 1988, 2004; Sear 2006; Welch 1998. The total amount of baths and spectacle buildings underlying the map of Fig. 10.1 is 1.501 .

${ }^{15}$ See, for example, Wilson 2011: 163-167; Jouffroy 1986.
} 


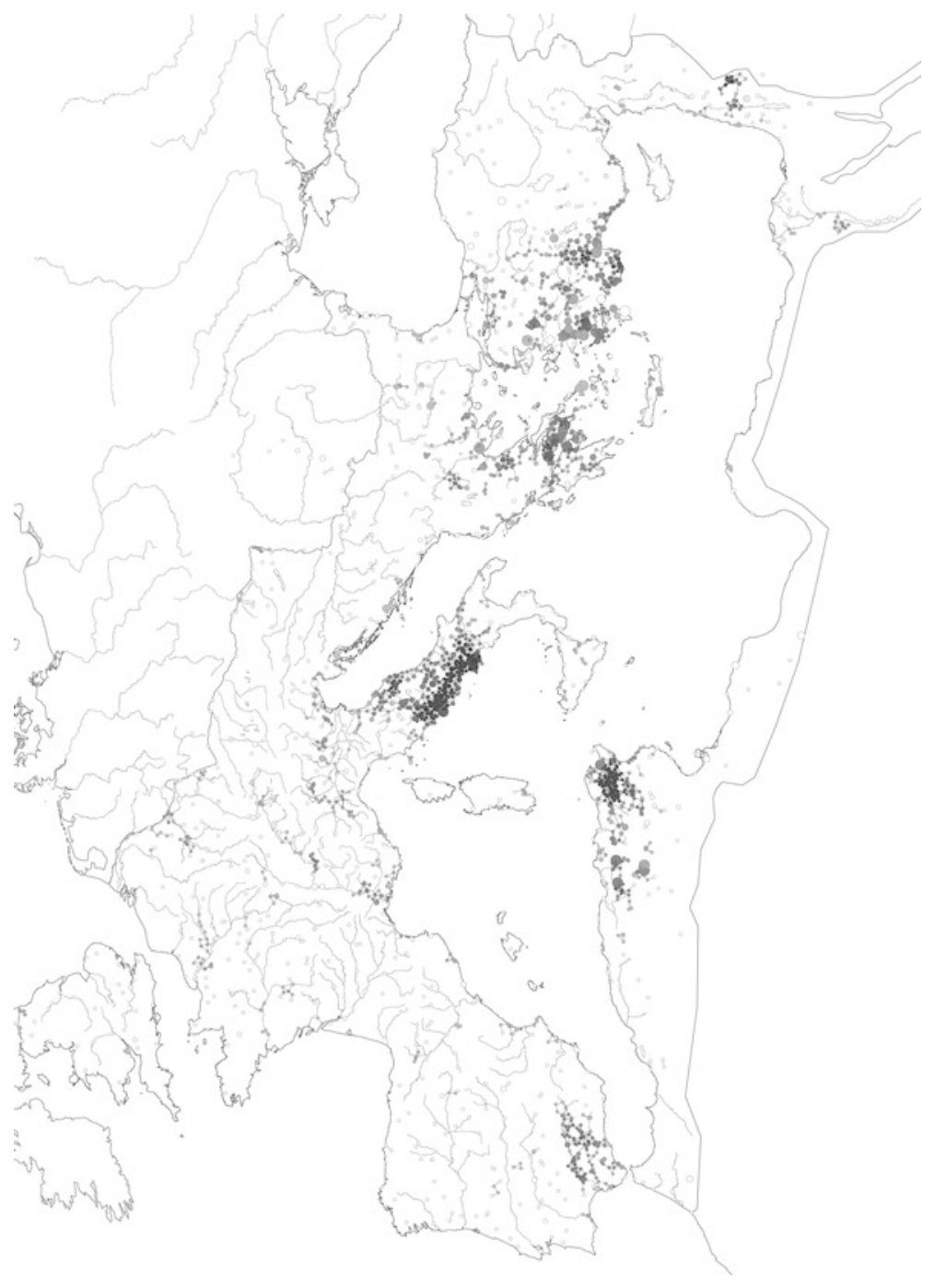

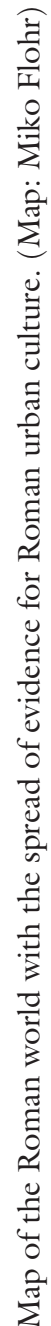

뭉 
sanctuaries or isolated bath spas. ${ }^{16}$ The emerging picture is clearest in the western half of the empire, where one can easily spot three clearly articulated clusters of urbanism:

- Central Italy, basically from the Bay of Naples in the south up to Rimini in the North. This is a very dense cluster, organized around the plains of Latium and Campania, and the Tiber Valley, but including large sections of the northern Apennines, and focused strongly on the road network.

- The North part of Africa Proconsularis, with a dense scatter of settlements around the Bagradas basin and the immediate hinterland of Carthage, that to some extent continues in northern Numidia, albeit less dense-again, this cluster appears to have been organized around overland connections, and mostly lacks direct connections to the coast.

- Baetica, with a dense cluster of mostly small cities in the Guadalquivir basin, which is at two points connected to the coast of the Mediterranean (at Carteia and Malaca), but otherwise organized around a network of roads.

Besides these three key clusters of urbanism, zones of less densely clustered evidence include northern Italy, particularly Transpadana, and the lower valley and delta of the Rhone. Otherwise, however, large parts of the Iberian Peninsula, Roman Europe, and Britain appear much less densely urbanized, and the same holds true for the western part of Roman Africa, Southern Italy, and Sicily. In the eastern half of the empire, the picture is comparable, with densely urbanized zones in Greece and Asia Minor, and much less densely urbanized zones in Anatolia and in large parts of the Near East.

In terms of the spread of urbanization and urban culture, there were thus sharp differences within the Roman world, and this has implications for ways in which information could circulate at the supra-local level. Within the clusters in Italy, Africa and Baetica, circumstances for the free circulation of information were relatively good. Urban centers were often

\footnotetext{
${ }^{16}$ The density of settlements was measured by counting, for each settlement, the number of settlements within a radius of $30 \mathrm{~km}$ as the crow flies. This distance was chosen as reflecting a journey of one day on foot, or one day back and forth by cart. The map highlights cities with more than two neighbors within this distance.
} 
literally within walking distance of each other, and the communities and economies of these cities and their territories often seem to have been well-integrated. There is quite a bit of epigraphic evidence for this: inscriptions mention patrons or patronesses active in multiple cities in a region, and there is significant evidence of people who ended up living in a neighboring city from where they were born. ${ }^{17}$ In several regions, there were regional market circuits, and there is literary evidence for cities on the coast serving as ports for neighboring cities. ${ }^{18}$ Moreover, these three regions also had strong and direct links with the food market of the city of Rome, with Baetica providing olive oil, Africa both oil and grain, and Italy an entire range of products, including wine. ${ }^{19}$ Thus, within these regions, information networks were not only defined by the physical proximity of population centers and by the development of infrastructure connecting these centers, but also by direct social and economic ties between urban communities, and by their integration into the economic networks supplying the Roman metropolis. This does not mean that the circulation of information was perfect, but the concentration of urban centers and the strong and direct connections between them highlight a relative absence of impediments within these regions: information could circulate with relative ease. Outside the densely urbanized regions, obstacles to the circulation of information were more serious. Communication beyond the local horizon was less straightforward, as the distance to neighboring communities was much larger: cities were considerably more isolated. There often were fewer direct economic ties with the city of Rome, or with the wider imperial economic network. This, of course, works against the circulation of information, and it is not hard to understand the regions with the lowest densities of urbanism in primitivist terms, with economies that were to a large extent locally oriented, and with infrequent connections at the supra-local level, particularly in the winter season. ${ }^{20}$ In terms of having frequent access to accurate information, it mattered whether

${ }^{17}$ For example, CIL 2.3278, referring to Valeria Petina, flaminica in Corduba, Castulo, and Tucci; CIL 9.2438 (169-172 AD) shows magistrates from Bovianum and Saepinum in Samnium operating together; CIL 9.6760 (from Aesernia, second century AD) shows these two cities had an eques, Flavius Celer, who was their shared curator.

${ }^{18}$ On these market circuits see De Ligt 1993. Strabo (5.3.8) recalls how Pompeii was the port city of Nuceria and Nola.

${ }^{19}$ On the impact of Rome see Morley 1996. On the role of Africa see Hobson 2015: 63-102; Mattingly 1995: 138-55. On Baetica see Haley 2003.

${ }^{20} \mathrm{See}$, for a vivid depiction of such a scenario, Bang 2008: 137-138. 
you lived in Ucubi in Baetica, surrounded by a range of small towns like Iptuci (Torreparedones, $17 \mathrm{~km}$ ), Ipsca $(14.5 \mathrm{~km})$, or Ulia Fidentia $(13 \mathrm{~km})$, and within a day's travelling from a large center like Corduba $(30 \mathrm{~km})$, or at Osca, in Northern Spain, where the nearest urban settlements-Caesaraugusta $(65 \mathrm{~km})$ and Ilerda $(105 \mathrm{~km})$-were both more than two days of travelling away. ${ }^{21}$

This differentiated picture was of course the result of several social, economic, and political developments that took place over a longer period of time, but Roman imperial hegemony - and the resulting demographic explosion of the Roman metropolis-must be seen as a key factor in bringing it about. ${ }^{22}$ While regions like Baetica and Africa were, to some extent, urbanized already before the imperial period, one clear development of the first centuries CE is the increasing differentiation between the urbanized and less densely urbanized regions of the empire, as new settlements seem to have emerged within already densely urbanized regions with higher frequency than elsewhere. ${ }^{23}$ This process is particularly clear in Africa and Baetica, but studies of Roman Italy have equally emphasized the extent of urban growth in the early imperial period. ${ }^{24}$ It is important to emphasize that this development was not only (or even mainly) a matter of demography: the data underlying the map reflect the existence of urban communities, but also their relative flourishing-they point to the activities of local elites involved in competitive construction and other forms of euergetism, and, thus, the presence of buying power, and of the consumer culture that characterized Roman imperial society. ${ }^{25}$ In other words, the clusters give a rough indication not only of the spread of people, but also highlight a geography of wealth and consumption. By implication, the cities in these clusters are likely to have been attractive, low-risk destinations for vestiarii and other traders in consumer goods-what could not be sold in one place, could perhaps be sold in the next, and if not there, then

${ }^{21}$ All distances were measured as the crow flies using Google Earth. Locations of the cities mentioned were based on Ahlfeldt's Digital Atlas of the Roman Empire, dare.ht.lu.se, May 8,2019 . Orbis gives a travel time of 2.3 days by foot from Osca to Caesaraugusta, and 3.5 days from Osca to Ilerda; orbis.stanford.edu, May 8, 2019.

${ }^{22}$ On the demography of Rome see Morley 2013.

${ }^{23}$ On the pre-Roman urbanization of Baetica see Houten 2018: 32-36.

${ }^{24}$ For Baetica see Haley 2003. For Africa see Sears 2011. Italy has been intensively discussed, but see, for example, Vermeulen 2017: 108-161.

${ }^{25}$ See for the flourishing of euergetism in the imperial period in general Jouffroy 1986; Patterson 2006; Zuiderhoek 2009. 
certainly somewhere nearby. More than the less densely urbanized and less wealthy regions, the clusters thus enabled itinerant traders to circulate, and to spread information that could feed directly into local knowledge of market situations. By implication, there was thus not only the possibility for information to circulate due to lower distances between urban centers, but also a clear economic drive for actors to actually move around. This was, to a much lower extent, the case outside the clustered areas-why go all the way from Osca to Caesaraugusta unless it was clear that the mission would not be in vain? In other words: there was a clear divergence between regions with increasingly low thresholds for information circulation, and regions that retained much higher thresholds for information circulation. This divergence was also known to exist: Cicero mentions how people living among the Bruttii and Sallentini in southern Italy-outside the cluster of urbanism in the center of the peninsula-were deprived of regular information flows and 'only got the news three times a year'-in Latium and Campania, he implies, things clearly were significantly better. ${ }^{26}$

It may be argued that, historically, the dense clusters of urbanism in Central Italy, Africa Proconsularis and Baetica were a completely new phenomenon of the Roman imperial period: the conditions for information circulation that can be reconstructed for these regions in the imperial period were unprecedented in the history of the Mediterranean region.

\subsection{URban Spaces}

On the local scale, the physical organization of the built environment was of key importance for the practical, everyday functioning of information networks. Within cities, the forum was the obvious key node in the urban information network: this was the place where relative strangers would normally encounter each other to conduct business, exchanging relevant market information in the process; the forum also was the place where such information would be easily available to relative outsiders to the community. ${ }^{27}$ Documentary evidence from the Vesuvian region confirms how business contracts were being negotiated and concluded on fora, or in the

${ }^{26}$ Cic. Rosc. Am. 132: 'aptam et ratione dispositam se habere existimant, qui in Sallentinis aut in Bruttiis habent unde vix ter in anno audire nuntium possunt'. Cf. Morley 1996: 72.

${ }^{27}$ On the role of the forum see Flohr 2020a; Laurence et al. 2011: 170-202. 
public buildings surrounding them. ${ }^{28}$ The physical concentration of a lot of banking activity in urban fora that is suggested by some literary sources implies that a lot of market information would be available in this environment. ${ }^{29}$ Of course, that fora were a critical node in urban information networks to a large extent is a product of the fact that they were the central-and in most cases the only-plaza in most Roman cities. In this sense, a Roman forum did not distinguish itself from a Classical Greek or Hellenistic agora. However, there is a little bit more to this: it can be argued that in the way in which fora developed architecturally, especially in the Late Republic and Early Empire, their role at the crossroads of everyday life was significantly strengthened. Three changes define this development: first, the appearance of long rows of tabernae around the plaza; second, the emergence of porticus surrounding the main forum square, and third, the introduction of the basilica.

Tabernae began to be constructed alongside fora from at least the third century BC onwards-early examples include the fora of Pompeii and Paestum (Fig. 10.2), and there is written evidence of early second century BC Roman censores surrounding urban fora in several places in Italy with tabernae in Livy. ${ }^{30}$ Not all fora would have tabernae, and some-like at Pompeii-lost them at a later moment, but the taberna remained a common element around fora of Italy in the imperial period and it would become standard in the fora of Roman Europe, including, as far as it is known, Spain. ${ }^{31}$ Only in Africa, the taberna remained somewhat exceptional around urban fora. ${ }^{32}$ The taberna is so common that it is often taken for granted, but its emergence must be seen as a radical innovation, which dramatically transformed the character of urban retail and manufacturing, enhancing both the predictability and findability of retail environments, and the ease of communication between shops and workshops and the outside world. ${ }^{33}$ Yet the open character of tabernae also had an impact on the information landscapes around fora, and not only in the sense that a lot of economic information concerning the functioning of these tabernae would be easily accessible, but also that there-quite simply-was a

\footnotetext{
${ }^{28}$ See, for example, Broekaert 2017. Cf. CIL 4.3340:155 (Pompeis in foro). TPSulp 1-18

(Puteolis in foro), 19 (Romae in foro Augusto). See also Flohr 2020a.

${ }^{29}$ For example, Vitr. De Arch. 5.1.2.

${ }^{30}$ Liv. 41.27; Lackner 2008: 271.

${ }^{31}$ Cf. Baratto 2003; Bouet 2012; Cavalieri 1999; Roberti 1995.

${ }^{32}$ Baaziz 1987.

${ }^{33}$ See also Ellis 2018.
} 


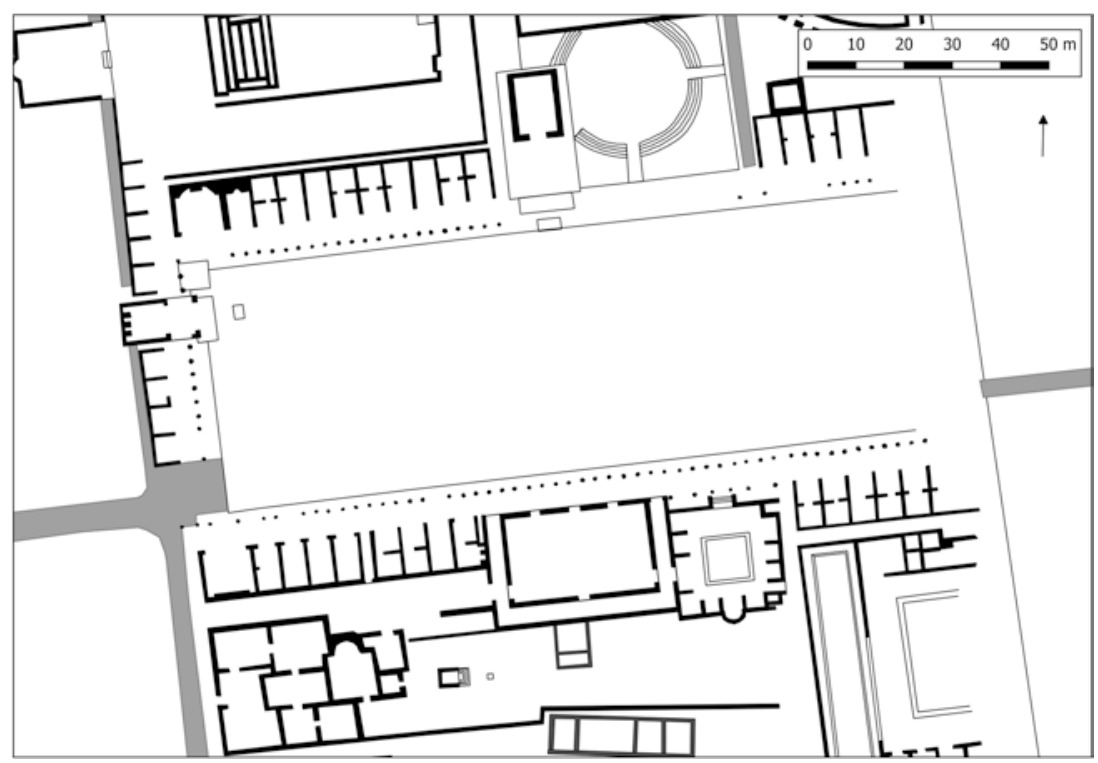

Fig. 10.2 Paestum. Plan of the forum area. (Plan: Miko Flohr)

more densely populated communication landscape in the forum area, and that information could circulate more easily.

From the second century BC onwards, most fora also began to be surrounded by porticus on all or most sides; at Pompeii, the first porticus appeared in the mid-second century BCE, in other Italian cities this appears to have happened around the same time or a little earlier. ${ }^{34} \mathrm{By}$ the first century BC, the porticus had become a standard hallmark of fora in Roman Italy (Fig. 10.3), and in the imperial period, it would become so in fora throughout the Roman world, particularly in Roman Europe and Africa-paradoxically, the Forum Romanum was one of very few fora in the Empire never to become fully surrounded by porticus, though the imperial fora were. ${ }^{35}$ The practical, functional impact of porticus should not be underestimated: architectural historians have often emphasized

${ }^{34}$ On the porticus of Popidius at Pompeii see (Pesando \& Guidobaldi 2006: 51-52. On the porticus in general see Frakes 2009; Lackner 2008: 271; Nünnerich-Asmus 1994.

${ }^{35}$ See on the forum and the imperial fora Coarelli 2008: 47-155. 


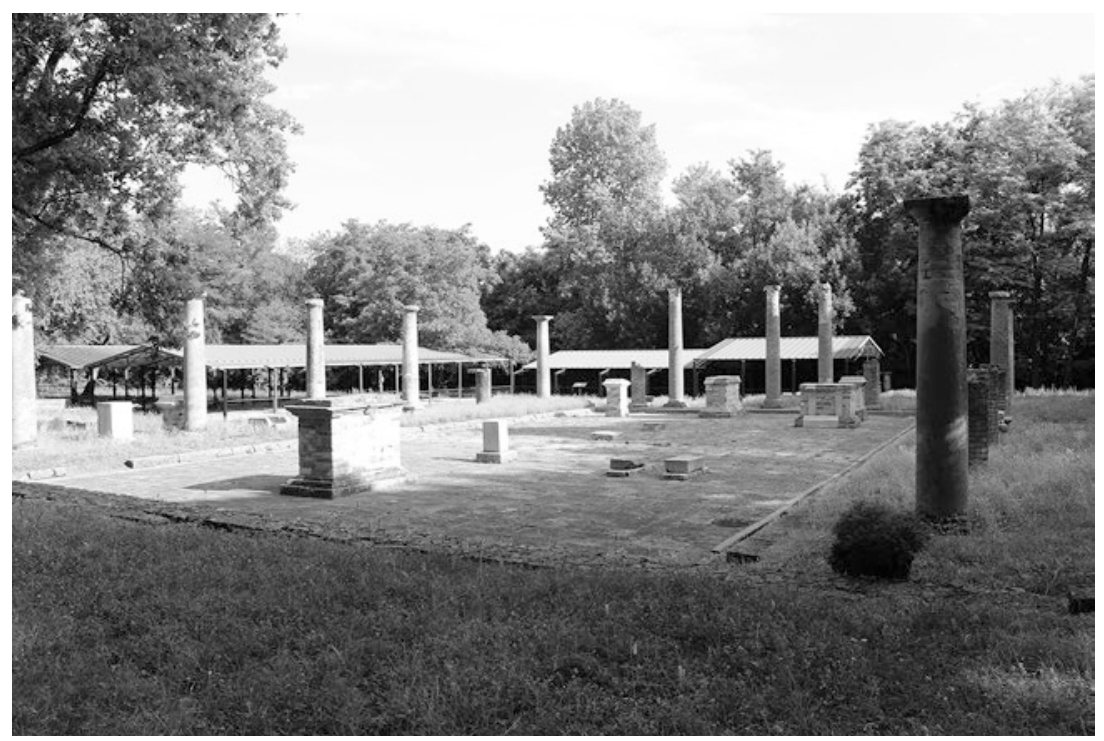

Fig. 10.3 Veleia. Augustan-era forum with plaza surrounded by porticus. (Photo: Miko Flohr)

their role in controlling the visual appearance of the square, but, obviously, porticus also functioned as covered walkways, and-crucially-could do so independently of weather and season, thus guaranteeing the continuing functionality and navigability of the forum environment during bad weather - whether it was too hot, too cold, too windy or too rainy, the porticus offered a possibility for people to hang around and meet up. ${ }^{36}$ This all-weather environment made it possible for information to circulate whatever the meteorological conditions.

What is true for the porticus is even more strongly the case for the basilica. ${ }^{37}$ After their first appearance around the Forum Romanum in the Republican period, basilicae would be constructed in large numbers in Italy in the last century of the Roman republic, and by the Augustan period, the basilica had become a standard element in formm architecture,

${ }^{36}$ On this issue see Flohr 2020 b.

${ }^{37}$ On the emergence and spread of the basilica see Gros 1996: 235-60; Lackner 2008: 266-71; Nünnerich-Asmus 1994. See also Laurence et al. 2011: 170-202. 


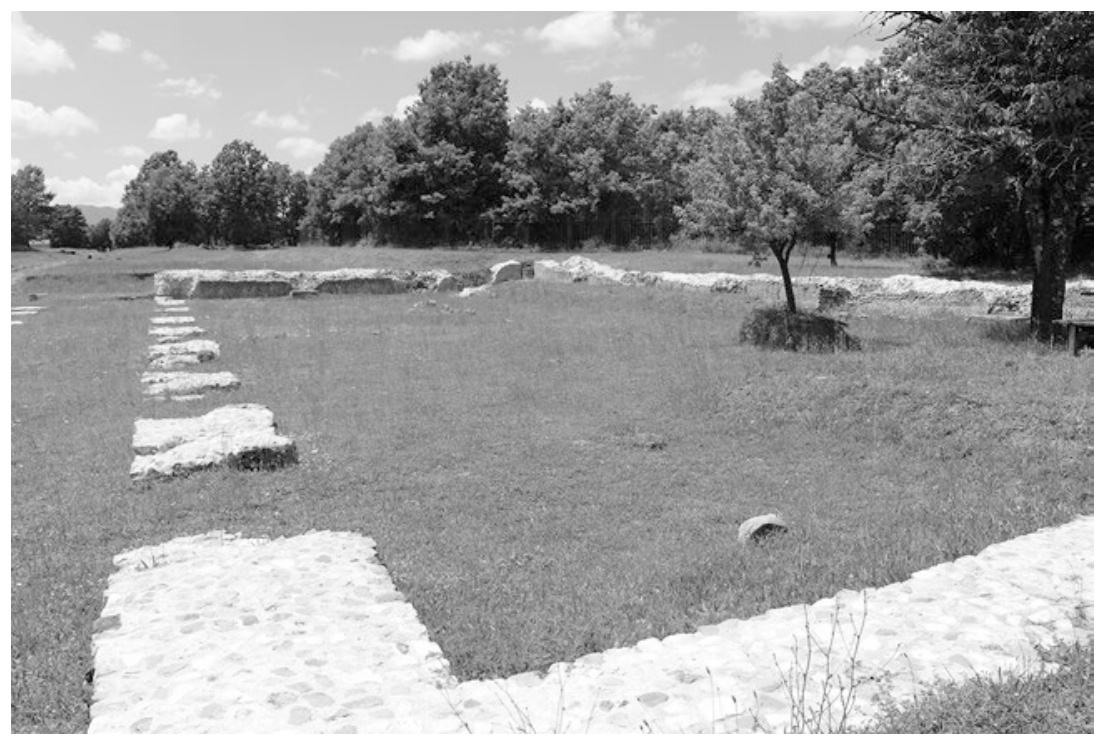

Fig. 10.4 Grumentum. Remains of Basilica. The forum is directly on the left. (Photo: Miko Flohr)

to be included in the initial design of new urban fora all over the Roman world. Essentially, the basilica was little more than a large hall (Fig. 10.4), which often had an extremely open connection with the forum or with the porticus around it, and while basilicae are sometimes associated with certain civic and juridical processes, in general, they have a rather vaguely circumscribed functionality. Indeed, rather than being constructed for a limited number of specific functions, one should think of the basilica as being the covered continuation of the forum square, again offering an allweather environment, but one that looks less like a corridor-as porticus did-and more like a destination space in itself. Significantly, this role of the basilica is made explicit by Vitruvius, who emphasized that basilicae should be constructed in a way that would allow business to continue in the cold season too. ${ }^{38}$

Thus, looking at the tabernae, the porticus and the basilicae of Roman fora - and the fora in places like Iuvanum and Veleia suggest that this is

${ }^{38}$ Vitr. De Arch. 5.1.4. 
true for urban fora as well as for those built in rural contexts-it is clear that the position of the forum as a key node in information networks was not only recognized by communities, but it also developed in a way that was very much conducive of a continuous circulation of information.

\subsection{URBAN LANDSCAPES}

It is important, however, to see the development of urban fora as a social meeting point in a slightly broader historical context. The forum may have been the key interface of a city with the outside world, it was not, of course, the only urban environment where information was exchanged, formally or informally, within the community. There were other public or semi-public venues too, and particularly baths, and their palaestrae, were common, everyday meeting points for all kinds of people within the community; epigraphic and archaeological evidence shows how baths, in the imperial period, and particularly in the second century $\mathrm{AD}$, became a common part of urban culture throughout the Roman world, with even medium-sized cities having multiple public bathing complexes. ${ }^{39}$ Literature also suggests how baths could be used by people from different households to catch up, informally. ${ }^{40}$ To a lesser extent, spectacle venues like theaters and amphitheaters could perform a similar role, though they were more incidentally used and not necessarily in contexts that fostered exchange of information between people that did not see each other otherwise. ${ }^{41}$ In any case, the direction of development suggested by the construction of baths and spectacle buildings is similar: from the late Republic to the imperial period, Roman urban information networks became denser, and better integrated.

Admittedly, information relevant for everyday economic processes did not necessarily circulate through such public encounters; a lot of the more relevant, high-quality information relevant to buyers and sellers may have been disproportionally concentrated inside private houses, and thus, harder to find for people without strong social ties in the community. In this context, it is relevant to highlight the impact of the taberna beyond the forum. The taberna facilitated interaction between craftsmen and

\footnotetext{
${ }^{39}$ See esp. Nielsen 1990; Patterson 2006: 130-60; Thébert 2003.

${ }^{40}$ See, for example, Apul. Met. 9.24-26. For a demographic breakdown of the visitors to Roman baths see Fagan 2002: 189-219.

${ }^{41}$ On these see Laurence et al. 2011: 231-84; Patterson 2006: 130-148.
} 
retailers and their prospective clients through their wide opening, and their spread over the urban landscape, which is particularly well-pronounced in Roman Italy, meant that it could play an important role in enhancing the circulation of information through the public sphere in the entire city (Fig. 10.5). ${ }^{42}$ Crucially, besides interacting with the outside public, tabernae also interacted directly with each other, and the retailers and craftsmen operating them worked often in direct hearing distance of each other. ${ }^{43}$ Moreover, as tabernae did not always have internal access to water, a lot of these people would meet regularly at public fountains. ${ }^{44}$ Thus, the spread of the taberna alongside urban thoroughfares further integrated urban communication landscapes, and made it easier for information to circulate within urban neigborhoods. This already removed some of the key barriers for the circulation of information coming from private houses in these neigborhoods.

Furthermore, many of the tabernae lining the urban streets of Roman Italy of course also had some structural relation with an atrium house or a more modest form of private domestic architecture. To judge from the archaeological record it is only in Rome and Ostia that this relation is

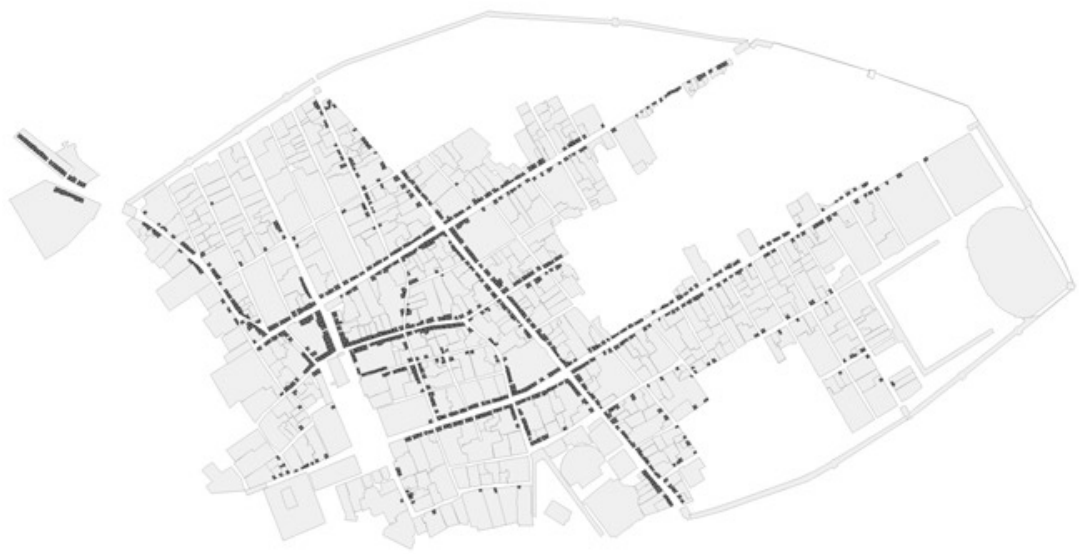

Fig. 10.5 Pompeii. Spread of tabernae over the city. (Map: Miko Flohr)

\footnotetext{
${ }^{42}$ On the archaeology of the taberna see Holleran 2012: 99-158, 2017.

${ }^{43}$ See, for example, Flohr 2016a:168-169.

${ }^{44}$ As is the case with the small fullonicae of Pompeii. Cf. Flohr 2013: 319.
} 


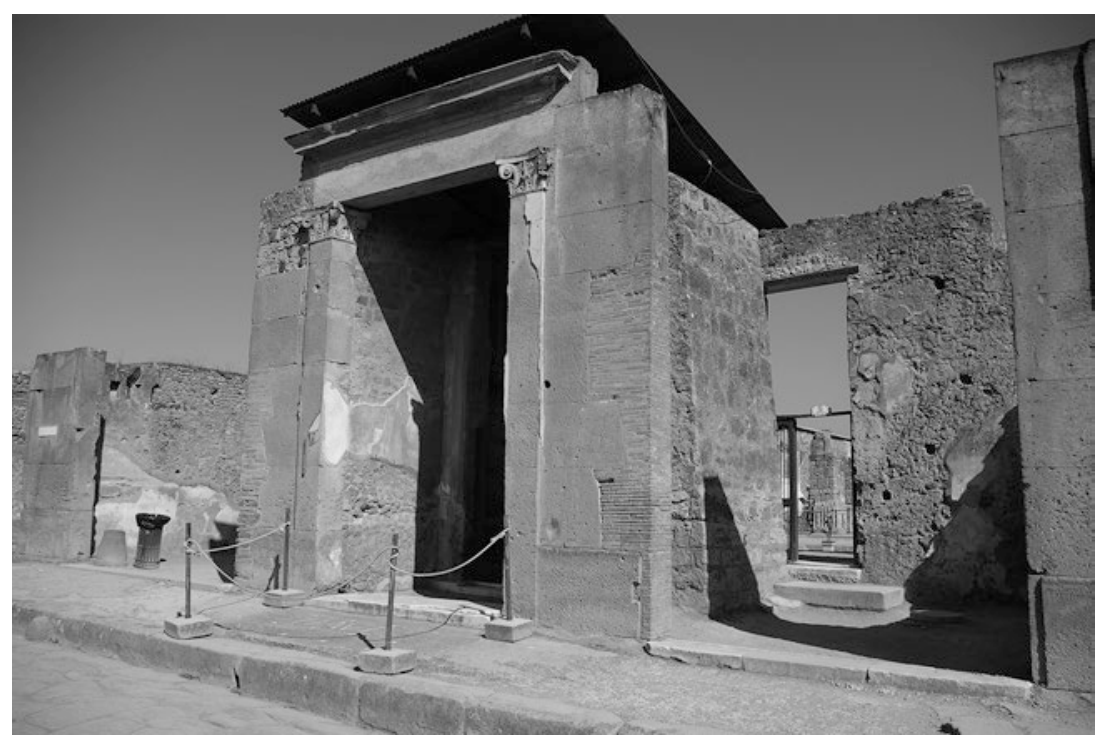

Fig. 10.6 Pompeii, House of the Faun. Taberna with internal connection to atrium. (Photo: Miko Flohr)

mostly absent. Indeed, many houses with tabernae also had one or two shops that had a direct connection with the main house (Fig. 10.6). ${ }^{45}$ Arguably, such connections were made, and retained, because they could actually be used by people to go from the shop to the house, or vice versa, and as such, they imply that there were meant to be direct, and continuous information ties between the taberna and the household; in other words, directly connected tabernae integrated houses with public urban information networks. Quite possibly, therefore, many new business connections between houses and partners from outside the immediate social network of the owners first started in or through the tabernae - or, conversely, the existence of tabernae made the establishment of such ties, and the exchange of relevant information that preceded this, quite a bit easier. The ways in which tabernae could be used to visually advertise the quality of what was

\footnotetext{
${ }^{45}$ At Pompeii, 284 of ca. 900 excavated tabernae had a direct internal connection to a house, while the total number of tabernae associated with houses (including both independent and internally connected tabernae) is 598. See for the underlying data Flohr 2018.
} 
on offer surely also helped in this respect; as the remains of façade paintings in Pompeii and Herculaneum make clear, this was not limited to the internal arrangement of the main room of the taberna, but also could include the façade. ${ }^{46}$

\subsection{Discussion}

It has been the intention of this chapter to highlight the ways in which developing urban networks and urban landscapes changed the way in which economically relevant information could circulate within and between cities in the Roman world. The argument is not supposed to imply that all obstacles for circulation were removed, or that Roman urban markets in general had access to of accurate, reliable information about what was happening elsewhere, or that all information traveled easily and freely through urban space. In absolute terms, there are clear reasons to assume that in most places in the Roman world, none of this was the case. Moreover, this chapter has neither argued that possibilities for communication were always used with a predictable frequency: it has not discussed the ways in which people actually were willing or able to share information, or whether there was a culture in which relevant information could be easily exchanged between relative strangers should they encounter each other. These are things that cannot be derived from archaeological remains or honorific inscriptions.

The point, rather, has been that in evaluating the role of asymmetric information in the Roman economy it is vital to understand how information may have been travelling through space, purposefully, or by word of mouth, and how easy it would have been for people to get essential market information when they arrived, as relative strangers, in a new place. What this chapter has argued is that throughout the Roman world, there were significant differences between cities in the quality of information that arriving traders could expect to be available locally, and that there were differences in the quality of urban information landscapes even if the general architectural tendency was toward more openness. Porticus and basilica spread throughout the Roman west, but the taberna was more

${ }^{46}$ The depiction of the activities in a textile workshop on the façade of house IX 7, 1-2 at Pompeii are a good example. Cf. Potts 2009. It has to be emphasized, however, that the actual spread of such paintings should not be overestimated. 
unevenly distributed, particularly outside Italy. ${ }^{47}$ Thus, the overall picture is one of greater divergence, not of a greater circulation of information in general. Nevertheless, it is also true that the extremely integrated information landscapes of Roman Italy, and to a lesser extent Baetica and Africa Proconsularis, had no previous parallel in antiquity, and reflect an unprecedented potential for at least regional economic integration.

So, what does this mean for the role of asymmetric information in everyday economic practice? It may be good to go back to the example of the vestiarius outlined at the start of this chapter and contrast the three clusters of urbanism in the Roman West with the more marginal zones of Roman Europe. Within regions like Baetica, Africa Proconsularis and Italy, the dense communication network, and the improved facilities for interaction within cities will have created a situation in which both the vestiarii and their prospective clients will have had reasonably reliable information about each other: clients will have been familiar with a wide range of textiles, and are likely to have had a rough idea of what these items would normally cost. Due to the nature of regional demand, vestiarii are likely to have been frequent guests on the urban fora, meaning that this information was not monopolized by individual traders-arriving traders would have to work from the idea that there might have been others before them who gave prospective customers an idea of what could be on offer against what price. This significantly limited their possibilities to exploit asymmetries of information, particularly regarding price levels, but also regarding the quality of the product. In the less densely urbanized areas, where cities were fewer and farther in between, and where regional markets were a less attractive investment in time and effort for itinerant traders, this was different. Local knowledge of products and prices would often be less up-to-date, and this generated asymmetries of information that could be exploited by traders, by pricing garments above their actual market value, or by abusing the reputation of certain clothing types or materials. ${ }^{48}$ For instance, in a remote region where vestiarii were uncommon, it would be easier to sell a fine black cloak as coming from Laodicea

${ }^{47}$ Frakes 2009; Laurence et al. 2011: 170-202. The limited spread of the taberna outside Italy was not explicitly noted by Ellis 2018, but it is implicit from the virtual absence of nonItalian tabernae throughout his analysis.

${ }^{48}$ See for comparable problems Bang 2008: 138. 
on the Lycus, or a white tunic as coming from Mutina without this actually being the case. ${ }^{49}$

Combining this differentiation in the role of information asymmetry with the historical development of the urbanized clusters in Baetica, Africa and Italy, and, indeed, in the Greek-speaking East of the empire, it becomes possible to return to the question outlined at the start of this chapter about the extent to which the changing physical shape and geographical structure of markets in the Roman world, impacted on the role that asymmetric information actually could play in everyday economic practice. Arguably, the clustered urbanization of the Roman Empire created a number of regions where asymmetries of information played an unprecedentedly small role in everyday transactions. This does not mean that they did not play a role at all, but it does mean that the growth of urbanized clusters to some extent limited the role of information asymmetry in the Roman economy. Arguably, this is an important development that should be an integral part of discussions about the role of information asymmetry in the Roman economy.

\section{BIBLIOGRAPHY}

Adams, C. 2012. Transport. In The Cambridge Companion to the Roman Economy, ed. W. Scheidel, 218-240. Cambridge: Cambridge University Press.

Akerlof, G.A. 1970. The Market for 'Lemons': Quality Uncertainty and the Market Mechanism. Quarterly Journal of Economics 84 (3): 488-500.

Baaziz, S.B. 1987. Les Forums Romains en Tunisie: essai de Bilan. In Los Foros romanos de las provincias occidentales, 221-236. Madrid.

Bang, P. 2008. The Roman Bazaar. Cambridge: Cambridge University Press.

Baratto, C. 2003. Le tabernae nei fora delle città romane tra l'età repubblicana e il periodo imperiale. Rivista di Archeologia 27: 67-106.

Bouet, A. 2012. Le forum en Gaule et dans les régions voisines. Bordeaux.

Broekaert, W. 2013. Financial Experts in a Spider Web. A Social Network Analysis of the Archives of Caecilius Iucundus and the Sulpicii. Klio 95 (2): 471-510.

- 2015. Recycling Networks. The Structure of the Italian Business Community on Delos. In Structure and Performance in the Roman Economy. Models, Methods and Case Studies, ed. P. Erdkamp and K. Verboven, 143-182. Brussels: Éditions Latomus.

${ }^{49}$ On wool from these regions see Flohr 2016b, 2017. 
2017. Conflicts, Contract Enforcement, and Business Communities in the Archive of the Sulpicii. In The Economy of Pompeii, ed. M. Flohr and A. Wilson, 385-412. Oxford: Oxford University Press.

Buonopane, A. 2003. Un vestiarius centonarius ad Aquileia: sulla genuinità di CIL, V, 50. Aquileia Nostra 74: 301-314.

Cavalieri, M. 1999. Il modello forum-basilica e la sua "evoluzione" tra la Cisalpina e la Narbonensis. Archeologia dell Emilia Romagna 3: 85-101.

Coarelli, F. 2008. Roma. Roma: Laterza.

Dari-Matiacci, G., S. Onderstal, and F. Parisi. 2011. Inverse Adverse Selection: The Market for Gems. Social Science Research Network.

De Ligt, L. 1993. Fairs and Markets in the Roman Empire. Economic and Social Aspects of Periodic Trade in a Pre-industrial Society. Amsterdam: Gieben.

Ellis, S.J.R. 2018. The Roman Retail Revolution. The Socio-Economic World of the Taberna. Oxford: Oxford University Press.

Erdkamp, P. 2005. The Grain Market in the Roman Empire. Cambridge: Cambridge University Press.

Fagan, G. 2002. Bathing in Public in the Roman World. Ann Arbor: University of Michigan Press.

Flohr, M. 2013. The World of the Fullo. Work, Economy and Society in Roman Italy. Oxford: Oxford University Press.

- 2016a. Constructing Occupational Identities in the Roman World. In Work, Labor and Professions in the Roman World, ed. K. Verboven and C. Laes, 147-172. Leiden: Brill.

- 2016b. The Wool Economy of Roman Italy. In Textiles, Trade and Theories. From the Ancient Near East to the Mediterranean, ed. K. Dross-Krüpe and M.-L. Nösch, 49-62. Münster: Ugarit.

- 2017. Textiles, Trade and the Urban Economies of Roman Asia Minor. In Wirtschaft als Machtbasis. Vormoderne Wirtschaftssysteme in Anatolien, ed. K. Piesker, 1-41. Berlin.

- 2018. Database of Pompeian Houses. Leiden: Miko Flohr.

- 2020a. Fora and commerce in Roman Italy. In Urban Space and Urban History in the Roman World, ed. M. Flohr, 198-220. London: Routledge.

- 2020b. Hilltops, Heat and Precipitation: Roman Urban Life and the Natural Environment. In Urban Space and Urban History in the Roman World, ed. M. Flohr, 66-85. London: Routledge.

Frakes, J. 2009. Framing Public Life: The Portico in Roman Gaul. Vienna: Phoibos Verlag.

Golvin, J.-C. 1988. L'Amphithéâtre romain. Essay sur la théorisation de sa forme et de ses fonctions. Paris.

Gros, P. 1996. L'architecture romaine: du début du IIIe siècle av. J.-C. à la fin du Haut-Empire. 1: Les monuments publics. Paris. 
Haley, E.W. 2003. Baetica Felix: People and Prosperity in Southern Spain from Caesar to Septimius Severus. Austin: University of Texas Press.

Hanson, J. 2016. An Urban Geography of the Roman World, 100 BC to AD 300. Oxford: Archaeopress.

Hobson, M. 2015. The North African Boom. Evaluating Economic Growth in the Roman Province of Africa Proconsularis. Portsmouth: JRA.

Holleran, C. 2012. Shopping in Ancient Rome: the Retail Trade in the Late Republic and the Principate. Oxford: Oxford University Press.

- 2017. Finding Commerce: The Taberna and the Identification of Roman Commercial Space. Papers of the British School at Rome 85: 143-170.

Horden, P., and N. Purcell. 2000. The Corrupting Sea. Oxford: Blackwell.

Houten, P. 2018. Civitates Hispaniae: Urbanisation on the Iberian Peninsula during the High Empire. Leiden: Leiden University.

Humphrey, J. 1986. Roman Circuses: Arenas for Chariot Racing. London.

Jouffroy, H. 1986. La construction publique en Italie et dans l'Afrique romaine. Strasbourg.

Lackner, E.-M. 2008. Republikanische Fora. Eine städtebaulich-historische Analyse. München.

Laurence, R., S.E. Cleary, and G. Sears. 2011. The City in the Roman West c. 250 $B C-c$. $A D$ 250. Cambridge: Cambridge University Press.

Manderscheid, H. 1988. Bibliographie zum römischen Badewesen. München.

- 2004. Ancient Baths and Bathing: A Bibliography for the Years 1988-2001. Portsmouth: JRA.

Mattingly, D.J. 1995. Tripolitania. London: Batsford.

Menella, G. 2000. Un negotiator vestiarius Cisalpinus et Transalpinus a Fara Novarese. Epigraphica 62: 125-135.

Morley, N. 1996. Metropolis and Hinterland. Cambridge: Cambridge University Press.

C 2007a. The Early Roman Empire: Distribution. In The Cambridge Economic History of the Greco-Roman World, ed. W. Scheidel, I. Morris, and R. Saller, 570-591. Cambridge: Cambridge University Press.

- 2007b. Trade in Classical Antiquity. Cambridge: Cambridge University Press.

- 2013. Population Size and Social Structure. In The Cambridge Companion to Ancient Rome, ed. P. Erdkamp, 29-44. Cambridge: Cambridge University Press.

Nielsen, I. 1990. Thermae et Balnea. The architecture and Cultural History of Roman Public Baths. Aarhus: Aarhus University Press.

Nünnerich-Asmus, A. 1994. Basilika und Portikus: die Architektur der Säulenballen als Ausdruck gewandelter Urbanität in später Republik und früber Kaiserzeit. Köln. 
Patterson, J. 2006. Landscapes \& Cities. Rural Settlement and Civic Transformation in Early Imperial Italy. Oxford: Oxford University Press.

Pesando, F., and M.-P. Guidobaldi. 2006. Pompei Oplontis Ercolano Stabiae. Roma.

Potts, C. 2009. The Art of Piety and Profit at Pompeii: A New Interpretation of the Painted Shop Façade at IX.7.1-2. Greece and Rome 56 (1): 55-70.

Rice, C. 2016. Mercantile Specialization and Trading Communities: Economic Strategies in Roman Maritime Trade. In Urban Craftsmen and Traders in the Roman World, ed. A. Wilson and M. Flohr, 97-114. Oxford: Oxford University Press.

Roberti, M.M. 1995. Forum et Basilica in Aquileia e nella Cisalpina romana. Udine.

Scheidel, W. 2014. The Shape of the Roman World: Modelling Imperial Connectivity. Journal of Roman Archaeology 27: 7-32.

Sear, F. 2006. Roman Theaters. An Architectural Study. Oxford.

Sears, G. 2011. The Cities of Roman Africa. Stroud: History Press.

Temin, P. 2013. The Roman Market Economy. Princeton: Princeton University Press.

Terpstra, T. 2013. Trading Communities in the Roman World. A Micro-Economic and Institutional Perspective. New York: Brill.

Thébert, Y. 2003. Thermes Romains d'Afrique du Nord. Rome.

Verboven, K. 2011. Resident Aliens and Translocal Merchant Collegia in the Roman Empire. In Frontiers in the Roman World. Proceedings of the Ninth Workshop of the International Network Impact of Empire (Durham, 16-19 April 2009), ed. O. Hekster and T. Kaizer, 335-348. Leiden.

Vermeulen, F. 2017. From the Mountains to the Sea: The Roman Colonisation and Urbanisation of Central Adriatic Italy. Leuven: Peeters.

Welch, K. 1998. The Stadium at Aphrodisias in Caria. American Journal of Archaeology 102: 547-569.

Wilson, A. (2011). 'City Sizes and Urbanization in the Roman Empire', in A. Bowman and A. Wilson (eds), Settlement, Urbanization and Population. Oxford: Oxford University Press, 161-195.

Zuiderhoek, A. 2009. The Politics of Munificence in the Roman Empire. Citizens, Elites and Benefactors in Asia Minor. Cambridge: Cambridge University Press. 